\title{
Recent Changes in the Upland Watershed Forest of Monasavu, a Cloud Forest Site along the PABITRA Gateway Transect on Viti Levu, Fiji ${ }^{1}$
}

\author{
Marika Tuiwawa ${ }^{2}$
}

\begin{abstract}
The Monasavu catchment was selected as an additional study site for biodiversity assessment at the top of the PABITRA wet-zone landscape transect on Viti Levu. The site consists of upland rain forest with cloud forest and a freshwater lake. The lake was constructed to supply hydroelectric power. The biota of the area has been little studied, but initial surveys indicate that many endemic species are present. Construction of the hydroelectric dam has led to some conflicts between the Fiji Electric Company and local landowners around Monasavu. Nevertheless, the unique cloud-forest habitat and the desire of the landowners to sustainably utilize their resources and protect wildlife makes Monasavu an important addition to the PABITRA Gateway Transect.
\end{abstract}

The Monasavu water catchment was included as an additional focal site in the PABITRA Gateway Transect during the Joint Analysis Workshop held in Fiji from $18 \mathrm{No}$ vember to 3 December 2002. The area is a major water catchment for the Waimimala River and Monasavu Dam. Its forest area thus became Protection Forest under the Forestry Act of the Fiji Republic. Major hydroelectric development has taken place in this upland and montane forest ecosystem. This is an example of habitat fragmentation brought about by resource development vital for the national economy. It is this aspect of protection management that makes Monasavu an exciting research site.

In this paper I (1) provide a brief overview of the location and geophysical background of the site; (2) highlight results of past biological studies carried out in the area; (3) provide an overview of major infrastructural development carried out in the area; (4) discuss the current environmental status and socioeconomic situation in the area; and (5) highlight reasons for the selection of the site as an addi-

\footnotetext{
${ }^{1}$ Manuscript accepted 19 April 2004.

${ }^{2}$ South Pacific Regional Herbarium, Institute of Applied Sciences, University of the South Pacific, Suva, Fiji (e-mail: tuiwawa_m@usp.ac.fj).
}

Pacific Science (2005), vol. 59, no. 2:159-163

(C) 2005 by University of Hawai'i Press

All rights reserved tional focal site along the Viti Levu PABITRA Gateway Transect.

\section{Site Location}

The Monasavu water catchment is located in the upland and montane cloud forest of the Rairaimakutu Plateau in central Viti Levu (Figure 1).

\section{MATERIALS AND METHODS}

Much of the information presented here about the flora and fauna of the Monasavu catchment area is based on review of a series of unpublished biological studies by Ryan et al. (1979). However, recent biological findings, including the rare and invasive plants and animal species in the area, are reported based on visits by the author since 2000 . Descriptions of the forest types, native birds, and herpetofauna were provided by various researchers during the recent PABITRA (Fiii) activities in the area in 2002 (Morrison 2003). Information on the social and economic issues in the Monasavu catchment is mainly from the author's experience as a landowner in the area and from discussions with other landowners.

\section{Past Biological Studies}

A vegetation survey carried out by Ash and Ash (1984) around the Nanuku Creek and 


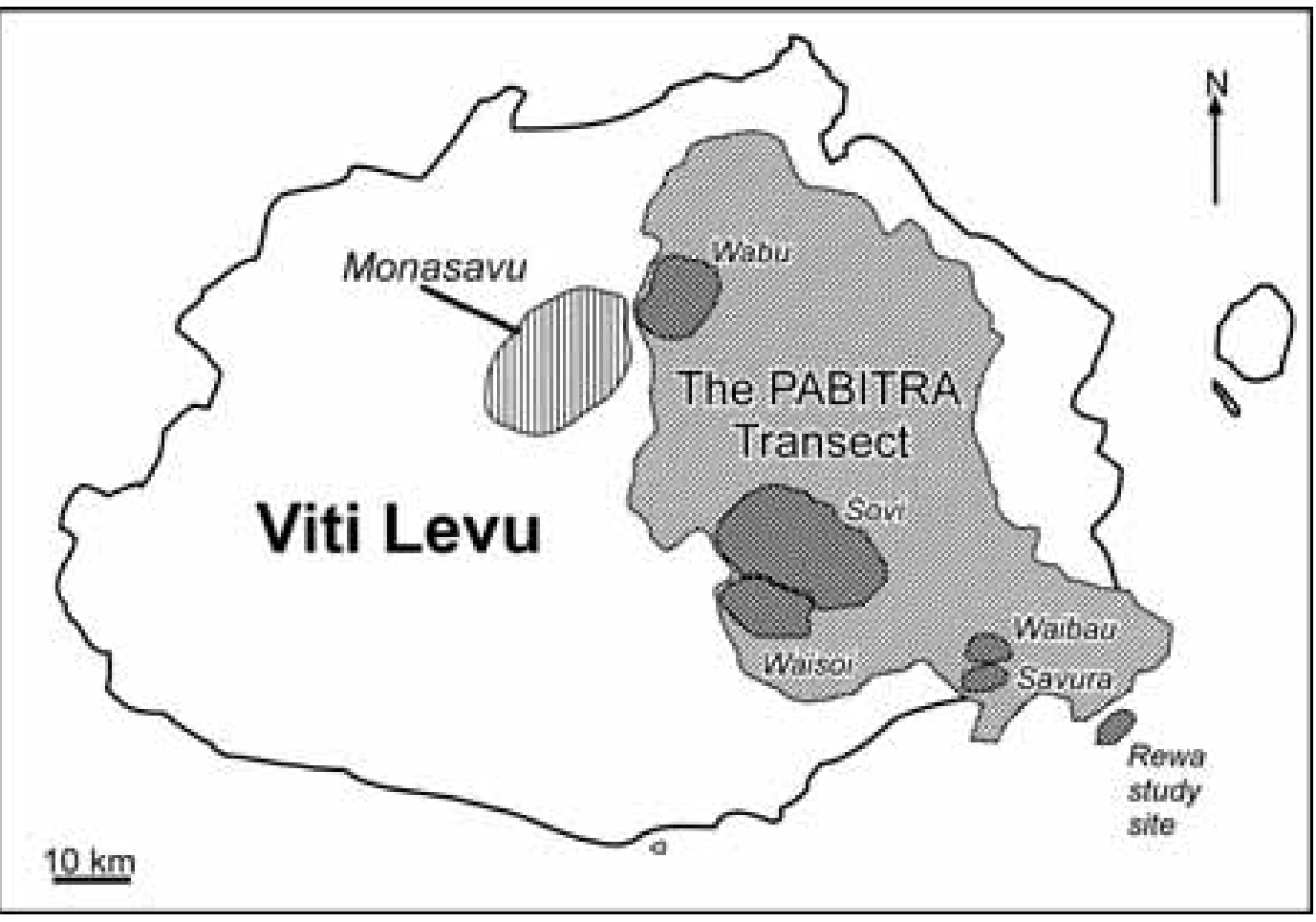

FIgURe 1. The island of Viti Levu, showing the location of Monasavu relative to the other focal sites along the PABITRA Gateway Transect. The geology and climate information for the area is treated in R. Kumar's article elsewhere in this issue.

the Monasavu Falls revealed that the most common $(>50 \%)$ emergent trees $(20 \mathrm{~m}$ tall) were Endospermum macrophyllum, Burkella thurstonii, and Parinari insularum. Canopy trees (15 m tall) were Macaranga graeffeana and Plerandra grayi. The subcanopy (up to $5 \mathrm{~m}$ tall) trees were Cyathea affinis, Palaquium hornei, and Parinari insularum; the understory on steep slopes comprised Heliconia paka, Clidemia birta, and Elatostema australe, and on ridge tops Clidemia birta and Alpinia sp. Among herbs and climbers the most common were Elatostema eximum, Elatostema filicoides, Epipremnum pinnatum, Peperomia parbamii, Freycinetia sp., Rubus moluccanus, Piper insectifugum, and Cordyline terminalis. Weeds and potential invasive plants recorded in Monasavu in 1977 included Mikania micrantha, Psidium guajava, Mimosa pudica, Sida acuta, Ageratum conyzoides, Ageratum boustonianum,
Hedychium gardnerianum, Ludwigia octovalvis, Cestrum nocturnum, Crassocephalum crepidiodes, Cuphea carthagenensis, Piper aduncum, Solanum toroum, and Clidemia birta.

A bird survey conducted in 1977 recorded 19 native bird species with $51 \%$ endemism.

\section{RESULTS AND DISCUSSION}

\section{Rare Endemic Trees}

A series of preliminary baseline surveys from 2001 to 2002 by the author of unique flora around Monasavu revealed the presence of the following relatively rare plant species: (1) Meryta tenuifolia (lutulutu): large tree with diameter of up to $1.5 \mathrm{~m}$. Found in moist forest east of Vanua Levu (Naga) village. It is endemic to central Viti Levu; (2) Schefflera costata: A large population of this shrub/tree 
was noticed on slopes along the road to Wainisavulevu. Endemic to Fiji and known to exist only from Taveuni and Mt. Tomaniivi; (3) Physokentia rosea: a subcanopy palm found in forests between the dam and Wainisavulevu. It is endemic and restricted to central Viti Levu; (4) Podocarpus affinis (kuasi): canopy tree found on ridges. An endemic podocarp found growing in high-altitude mountaintops and ridges of Viti Levu.

Very little else is known about the flora because no detailed floristic work has been done in the area.

\section{Vegetation}

There are three major forms of upland vegetation types found in the catchment: (1) the montane forest, which is restricted to slopes and gullies with elevations ranging from ca. 750 to $950 \mathrm{~m}$ above sea level (a.s.l.). Here the trees can grow up to $25 \mathrm{~m}$ in height and attain diameters at breast height of up to $2 \mathrm{~m}$; (2) the cloud montane forest is restricted to areas with elevations of greater than $1,000 \mathrm{~m}$ a.s.l. Here the vegetation is generally stunted (2-4 m high), covered in clouds, stems of trees are covered with mosses, the substrates are constantly wet, and plants are literally soaked in water at all times; and (3) upland freshwater swamp. The swamp is referred to as a montane peat bog by Scott (1993) and is called the Nadrau Swamp. It is in a side valley on the upper reaches of the Nanuku Creek at an elevation of about $950 \mathrm{~m}$ a.s.l. The wetland vegetation is herbaceous dominated by Eleocharis sp. and Coix lacryma-jobi.

\section{Invasive Species}

Undesirable plant species referred to as "invasive" occupy areas that are heavily impacted from development such as road works, settlements, and grazing areas. In Monasavu the following invasive species have already impacted the native vegetation: Piper aduncum, Solanum torvum, Clidemia birta, Merremia peltata, and Coriaria ruscifolia. Both Merremia peltata and Coriaria ruscifolia are native to Fiji. The former is a serious and problematic invasive climber and the latter is a shrubby thicket-forming plant that assumes a role in the early succession process.

Other weeds and potential invasive species recorded from Monasavu in 1977 that were still present in 2002 included Mikania micrantha, Psidium guajava, Mimosa pudica, Sida acuta, Ageratum conyzoides, Ageratum boustonianum, Hedychium gardnerianum, Ludwigia octovalvis, Cestrum nocturnum, Crassocephalum crepidioides, and Cuphea carthagenensis (Ryan et al. 1979). The presence of cattle and horses in the area contributes greatly to the spread of these invasive species. These free-grazing domesticated animals are found along regularly used roads and especially in flat areas along the edge of the lake toward the Nadrau Swamp.

The exotic fish species Tilapia and Grass Carp were noticed to be plentiful in the lake. Their impact on the native fish species is not known. Five exotic bird species now found in the area were not recorded during the 1977 survey. They include the two mynah bird species Acridotheres fuscus and Acridotheres tristis; the Spotted Dove, Streptopelia chinensis, and the Red Avadavat, Amandava amandava. The introduced bulbul Pycnonotus cafer was also noticed in the area and so was the mongoose Herpestes auropunctatus.

\section{Native Fauna}

Among 39 birds listed in the 2002 survey (Birdlife International 2003), 35 were native. Of the native species 18 were endemic to Fiji. The more important recent records for the area are as follows: (1) Red-throated Lorikeet, Charmosyna amabilis, a rare endemic and Fiji's most threatened bird; (2) Pinkbilled Parrotfinch, Erythrura kleinschmidti, a rare endemic and endangered bird; (3) Giant Forest Honeyeater, Gymnomyza viridis, a common endemic bird species and vulnerable to habitat loss; (4) Masked Shining Parrot, Prosopeia personata, an uncommon endemic bird vulnerable to habitat loss; (5) Longlegged Warbler, Trichocichla rufa, a rare indigenous species recorded only once in 1977 from the Monasavu area. The 2002 sighting was the first recent record for Fiji.

Most bird species recorded in the 1977 bi- 
ological survey were also sighted during the 2002 survey. The only bird not recorded was the Peregrine Falcon, Falco peregrinus. The Monasavu Dam area combined with Mt. Tomaniivi, the Wabu catchment, and the extensive forests toward Wainisavulevu are globally important as a home range for birds. The sighting of the Long-legged Warbler is the first "confirmed" record for many years, but the true status of this species is poorly known (Birdlife International 2003).

A Fiji tree frog, Platymantis vitiensis, was also found near the campsite. This find may indicate a good local population present in the area. This amphibian is difficult to locate in other areas of Fiji (Morrison 2003).

\section{DAM CONSTRUCTION AND SOCIOECONOMIC CONSIDERATIONS}

\section{View of Major Infrastructural Development}

The Monasavu water catchment covers an area of some $110 \mathrm{~km}^{2}$. The lake and dam were established in 1982. The lake covers an area of 670 ha. It is $1.5 \mathrm{~km}$ at the widest stretch and $10 \mathrm{~km}$ long with a maximum depth of $80 \mathrm{~m}$. The dam is $75 \mathrm{~m}$ high. There is an access road $24 \mathrm{~km}$ long. The tunnel that carries water from the Monasavu Dam to the Wailoa Power Station is $5.5 \mathrm{~km}$ long. The last $0.5 \mathrm{~km}$ toward the power station is inclined at an angle of 45 degrees. The dam currently produces $80 \mathrm{MW}$ of electricity (John Robinson, Monasavu Dam manager, pers. comm.).

\section{Current Sociological Issues}

Social changes have been brought about by an increase in the local population, better education, and greater dependence on a cash economy. This has caused much social disenchantment among the landowners around the catchment. Their limited access to utilize the resources in the water catchment area (i.e., logging, land for farming, streams for fishing) adds to this. The notion that they are being unfairly compensated in terms of what they are getting back from the use of their land has been the cause of conflict between the land owners, the Fiji Electricity Authority (FEA) (the statutory body that provides electricity for the country), and the Native Land Trust Board (NLTB) (the statutory body that administers native-owned resources). Most resource owners just recently got electricity despite it being available to others for the past 20 yr. During the construction of the dam, some landowners lost more than $70 \%$ of their land; thus members of this clan have very little land to live on. Strict restriction for locals to move in and out of the catchment adds to their frustration. All this has resulted in legal proceedings being put into place for compensatory purposes. The resolution of these conflicts remains a difficult legalistic problem.

\section{CONCLUSIONS}

The desire of the landowners to sustainably utilize their resources and protect the wildlife in the Monasavu area is encouraging. The highest point in the area $(1,100 \mathrm{~m}$ a.s.l. $)$ is accessible by dirt road, and the availability of good accommodations build by the FEA makes the area ideal for field research. So far, little is known about the vegetation ecology, biodiversity, and its functioning in the context of this montane tropical ecosystem. Thus the Monasavu catchment area was selected as an additional focal site for PABITRA (Fiii) because of the geophysical, biological, and sociological challenges it provides.

\section{Literature Cited}

Ash, J., and W. Ash. 1984. Freshwater wetland vegetation of Viti Levu, Fiji. N. Z. J. Bot. 22:371-396.

Birdlife International. 2003. PABITRA transect: Preliminary survey findings: Birds. Page 64 in C. Morrison, ed. APN/PABITRA Field biology techniques training and joint analysis workshop, University of the South Pacific, Fiji Islands, 18 November-3 December 2002. IAS Technical Report No. 2003/07. Institute of Applied Sciences, University of the South Pacific, Suva, Fiji. 
Morrison, C. 2003. PABITRA transect: Preliminary survey findings: Herpetofauna. Page 65 in C. Morrison, ed. APN/PABITRA Field biology techniques training and joint analysis workshop, University of the South Pacific, Fiji Islands, 18 November-3 December 2002. IAS Technical Report No. 2003/07. Institute of Applied Sciences, University of the South Pacific, Suva, Fiji.

Ryan, P. A., D. C. Hassal, S. C. Choy, N.
Penn, and J. S. Ryland. 1979. Biological studies conducted in the Wainisavulevu Creek, Viti Levu. Unpublished report; available from Institute of Applied Science, University of the South Pacific, Suva, Fiji.

Scott, D. A., ed. 1993. A directory of wetlands in Oceania. International Waterfowl and Wetlands Research Bureau, Slimbridge, Gloucester, U.K., and Asian Wetland Bureau, Kuala Lumpur, Malaysia. 
